
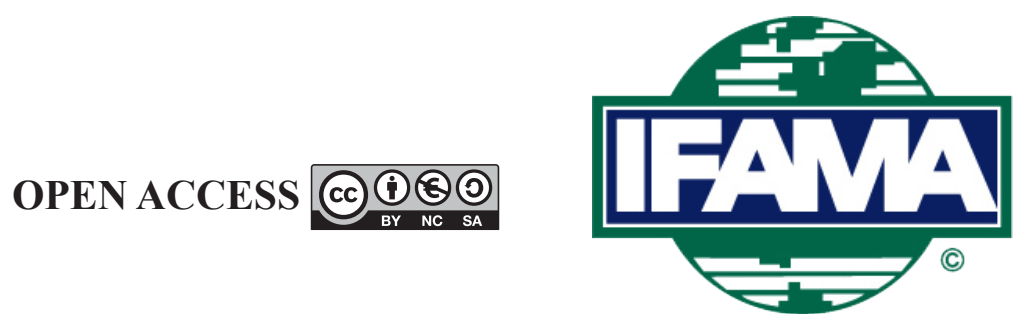

International Food and Agribusiness Management Review

Volume 24, Issue 3, 2021; DOI: 10.22434/IFAMR2019.0215

Received: 28 March 2019 / Accepted: 20 November 2020

\title{
Exploring variability across cooperatives: economic performance of agricultural cooperatives in northern Ethiopia
}

\section{RESEARCH ARTICLE}

\author{
Kifle T. Sebhatu ${ }^{\mathrm{a}, \mathrm{b}}$, Tafesse W. Gezahegn ${ }^{\mathrm{b}, \mathrm{c}}$, Tekeste Berhanu ${ }^{\mathrm{d}}$, Miet Maertens ${ }^{\mathrm{e}}$, \\ Steven Van Passel $^{\mathrm{f}}$ and Marijke D’Haese ${ }^{\circledR g}$ \\ ${ }^{a}$ Researcher, ${ }^{g}$ Professor, Department of Agricultural Economics, \\ Ghent University, Coupure Links 653, 9000 Ghent, Belgium \\ ${ }^{b}$ Researcher, ${ }^{d}$ Professor, College of Business and Economics, \\ Mekelle University, P.O. Box 451, Mekelle, Ethiopia \\ ${ }^{c}$ Researcher, ${ }^{e}$ Professor, Department of Earth and Environmental Sciences, \\ KU Leuven, Celestijnenlaan 200e, 3000 Leuven, Belgium

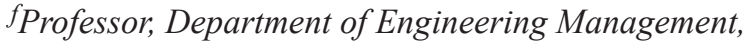 \\ University of Antwerp, Prinsstraat 13, 2000 Antwerp, Belgium
}

\begin{abstract}
The number of agricultural cooperatives increased quickly in Ethiopia since the 1990s. While many papers studied the impact of membership of Ethiopian cooperatives, not much is known on their performance. This study takes a cooperative-level perspective which is unique in an African context. It compares the economic performance proxied by sales revenue and profit of a wide range of agricultural cooperatives in northern Ethiopia. Data were collected from 511 agricultural cooperatives in 12 districts of Tigray. The contributing factors of the performance are analyzed with Ordinary Least Squares regression (OLS) and Heckman selection models. Our results underscore the importance of membership size, total assets, presence of conflict among members, and union membership. Chairperson characteristics and the internal organization of a cooperative seem to be less correlated to performance.
\end{abstract}

Keywords: agricultural cooperatives, performance variability, profit, audit, Ethiopia JEL code: Q12, Q13

\footnotetext{
${ }^{\oplus}$ Corresponding author: marijke.dhaese@ugent.be
} 


\section{Introduction}

As a result of cooperative development policies since the market liberalization campaigns in the 1990s, the cooperative movement across Africa has been expanding, diversifying and growing at a rapid pace (Wanyama et al., 2009). The government of Ethiopia promotes cooperatives as one of the main pillars of service provision support policies that aim at boosting agricultural transformation, improving food security and reducing rural poverty. As a result of the government's Agricultural Development Led Industrialization strategy launched in 1990, the number of cooperatives has been growing throughout the Ethiopian agricultural sector (Bernard et al., 2010). Cooperatives have also been attributed a major role in the more recent Agricultural Cooperative Sector Development Strategy 2012-2016, and the Growth and Transformation Plans (ATA, 2012; MoFED, 2010).

Many studies on African cooperatives point to the potential positive impact of membership on farm-gate prices (Bernard et al., 2008b; Fischer and Qaim, 2012), increased farm income of members (Ahmed and Mesfin, 2017; Getnet and Anullo, 2012; Mojo et al., 2017; Shumeta and D'Haese, 2016; Verhofstadt and Maertens, 2015), improved farm productivity (Ariyaratne et al., 2006; Chagwiza et al., 2016), increased farm technical efficiency (Abate et al., 2014; Ahn et al., 2012; Huang et al., 2013), increased adoption of modern inputs (Abebaw and Haile, 2013; Verhofstadt and Maertens, 2014; Wossen et al., 2017), and increased product quality (Cai et al., 2016). Some other studies (e.g. Cechin et al., 2013; Chagwiza et al., 2016; Pennerstorfer and Weiss, 2012; Soboh et al., 2009) refute the positive impact of cooperative membership. Grashuis and $\mathrm{Su}$ (2019) provide an extensive overview of studies on member benefits. Many studies so far have focused on member-level performance and their results are mixed (Abebaw and Haile, 2013; Bernard et al., 2008b; Chagwiza et al., 2016). Cooperative-level studies are scarcer in the African context compared to that of Western countries. A review by Benos et al. (2018) distinguishes performance studies at cooperative level based on the outcome variable that was used, namely business financial, business efficiency, or subjective business indicators. Of interest to this paper, the business financial cooperative literature uses financial ratio analysis (e.g. profitability, liquidity, debt ratios) or sales-based metrics (e.g. sales growth, market share) to compare the performance of cooperatives with that of firms (Grashuis, 2018; Guzmán and Arcas, 2008; Melia-Marti and Martinez-Garcia, 2015). The business efficiency measurement uses production function data for efficiency assessment and comparisons (Franken and Cook, 2015; Soboh et al., 2009). In this overview of cooperative performance studies, only a handful consider African agricultural cooperatives (Benos et al., 2018) despite their widespread occurrence. The discrepancy between the high number of member-level impact studies and fewer cooperative-level studies is remarkable. This can be attributed to, first, the complexity of data collection as exemplified in some recent cooperative-level studies in the African context that use smaller samples (Mathuva, 2016; Mathuva et al., 2016; Sisay et al., 2017; Wouterse and Francesconi, 2016). Secondly, at member-level, it might be easier for researchers to find a proxy for the counterfactual. Finally, measuring performance at the cooperative-level might be difficult given the complex objectives of cooperatives.

Performance, which is defined as the 'progress toward achieving pre-determined objectives' (Bourne et al., 2003: 6), is not an easy concept to grasp, especially in cooperatives as the relationship between the 'firm' and its objectives is not accurately defined (Soboh et al., 2009). Since cooperatives are in essence hybrid institutions characterized by member ownership, member control, and member benefits (Ménard, 2004), the benefits members get arguably depend on the performance at both collective and member level. As such, members will benefit from the way cooperatives function (Nilsson, 2001) and the cooperative itself benefits from the member's patronage to the cooperative (Wollni and Fischer, 2015). These particular cooperative features complicate the definition and measurement of economic performance of cooperatives. Moreover, as cooperatives are complex organizations that may serve a variety of purposes and perform a wide variety of functions, there may be no single objective that is generally accepted by all members (Royer, 2014).

In this paper, we embrace these challenges and take a cooperative-level perspective. We aim to add insights into factors affecting the variability of cooperative performances, using cooperative sales and gross profit as 
performance indicators. Earnings (profit) maximization and increasing sales are among the many objectives a cooperative may pursue (Royer, 2014). Although cooperatives, unlike profit-oriented firms, do not move where profit might be the highest, this does not mean that cooperatives can sustain themselves without achieving a certain level of financial success nor does it mean that members do not want economic stability. Thus, for cooperatives to survive, and to address their members' needs, they need stable and sufficiently high capital levels. This requires a sound economic performance.

Field experience shows a wide variability in performance across Ethiopian agricultural cooperatives. Some suffer from a lack of sufficient capital, poor management and/or failure to modernize their operation, lack of adequate supervision by the board, and a general disincentive to behave cooperatively, overdependence on the government, and serious governance or institutional capacity problems (Bernard et al., 2008a; Fulton and Hueth, 2009; Tefera et al., 2017). Some cooperatives are government- or NGO-initiated and may (partly) depend on this external support (Bernard et al., 2008b; Tefera et al., 2017) while others are grassroots initiatives. While they share the key member-owned and member-controlled characteristic, cooperatives widely differ in function, structure and management support. Yet, we lack evidence and insights on how these cooperative characteristics impact on their performance.

In this paper, we aim to fill this gap in research with empirical evidence on economic performance, proxied by sales and profit, across an extensive sample of agricultural cooperatives. We seek to explain the differences in performance we find based on cooperative-level governance and structural characteristics. Understanding performance variability determinants is particularly relevant because the country aims to transform the agricultural sector via increasing smallholder commercialization and ensuring value-added processing. We use a unique data set of cooperative-level information from the Tigray region of Ethiopia.

The paper continues as follows. The next section explains the empirical approach and gives a brief summary of agricultural cooperatives in Ethiopia and Tigray. We then present the study area and sampling technique, and detail the model specification. This is followed by a presentation of the discussion and results. The final section gives some concluding remarks.

\section{Empirical approach}

\subsection{Dependent variable: performance at cooperative level}

The boundaries of the cooperative as a 'firm' are not well-defined. Also the organizational forms are highly diverse, which makes a comparative analysis of the performance of cooperatives particularly challenging (Soboh et al., 2009). Moreover, cooperatives have a dual purpose of maximizing profit at both member and cooperative levels (Feng and Hendrikse, 2012; Soboh et al., 2009). As such, multiple objectives arise that may be different for the cooperative compared to its members (Soboh et al., 2009). Yet, it is reasonable to assume that most cooperatives need to operate in such a way that their economic performance is at least sufficiently high enough for it to keep afloat from one year to another.

Commonly used measures of economic performance in empirical studies include profitability or return on assets and growth in sales (Dess and Robinson Jr, 1984; Soboh et al., 2009). Other performance indicators that appear in the literature include financial ratios (Benos et al., 2018), efficiency indicators (Ariyaratne et al., 2000; Guzmán et al., 2009; Hailu et al., 2005; Sexton et al., 1989; Sueyoshi et al., 1998), overall organizational performance (Alho, 2015; Benos et al., 2016; Galdeano-Gómez et al., 2006; Tana et al., 2017), overall satisfaction with cooperative (Arcas-Lario, 2014; Bhuyan, 2007; Figueiredo and Franco, 2018; Liebrand and Ling, 2014), and social capital (Feng et al., 2016; Hansen et al., 2002; Susanty et al., 2017). In this study, we consider two performance indicators: (1) total sales measured by total income generated from core operational activities; and (2) gross profit calculated by subtracting costs from revenue after the cooperative is audited. This is in line with other studies; e.g. Liang et al. (2015) studied agricultural 
cooperatives in China using sales and sales per member as performance measures. Similarly, Boyd et al. (2007) and Grashuis and Cook (2016) used profitability as a cooperatives' performance indicator.

We acknowledge the limitations of these measures of performance as they are mainly operational indicators and may only be partial indicators of the cooperatives' effectiveness in achieving long-term targets or strategies. The measures used may also fail to provide a unified and representative assessment of the overall performance of cooperatives (Salmi and Martikainen, 1994) and may not necessarily be the best indicators (Grashuis and Cook, 2016). Yet, they may allow to show the variability in performance, which was pointed out in earlier studies, but only addressed by few authors so far (Bernard et al., 2008b; Spielman and Bernard, 2008).

\subsection{Independent variables}

This paper sets out to explain variability of performance across cooperatives by their governance and structural characteristics. The way a cooperative is established, owned, and governed arguably influences its performance.

\section{- Member control and governance characteristics}

A better educational level of directors and chairs is supposed to improve the cooperative's performance (Burress and Cook, 2010). Carpenter and Westphal (2001) also suggest that managerial experience may lead to better decision-making and enhance performance. As experience increases, chairs become more familiar with cooperative activities, which in turn improves performance (Cook and Burress, 2013).

The number of committees may have both positive and negative impacts on performance. The impact of fewer committees may be positive (Jensen, 1993; Yermack, 1996) as fewer opinions in the boardroom result in faster and less costly decision-making and monitoring on activities (Klimek et al., 2009). Following this thought, a larger number of committees, including a larger number of members participating in these committees, may induce problems of free-riders, control, and influence costs (Cook, 1995) and it is more challenging to monitor managers of a large number of committees. Influence costs can arise between committees with heterogeneous, and sometimes conflicting interests. Conversely, a larger number of committees may point to commitment. The presence of audit committees responsible for overseeing the financial reporting process and ensuring objectivity of financial performance (McMullen and Raghunandan, 1996) may be key to enhance performance as they deter members and directors alike to commit financial fraud. The existence of audit committees within the governance structure may indicate board oversight on financial risks and inspection accounts (Cook and Burress, 2013). Cooperatives are required to prepare accounting entries periodically and maintain financial transactions. This may depend on the knowledge and experience of boards and audit committees in supervising and overseeing financial accounts. Account preparation can play a major role in preventing, detecting and reducing financial fraud by cooperatives, thereby increasing their financial performance. Financial compensation for directors improves the financial performance of the cooperative (Spear, 2004).

Gender diversity among board members has attracted increasing scholarly attention (Adams and Ferreira, 2009). Quotas are enforced not only for the sake of equality but also for governance and performance, where women directors are expected to add a diversity of skills and opinions to the male-dominated boards. Gender diversity adds new perspectives and experiences to the board that leads to flexible thinking and creative problem-solving (Grashuis and Cook, 2016), which, in turn, improves the competence profile of the directors (Carter et al., 2003; Rose, 2007), and is expected to reduce the control problem between managers and members (Yang and Chaddad, 2014).

Indicators used to signal agency problems include conflicts, fraud and membership policy. Cooperatives may face conflicts between stakeholders due to overlaps in responsibilities, individual differences in personality, and resource allocation. Such conflicts may have a negative effect on performance (Cook, 1994). Fraud has 
an impact on financing costs, investment decisions and shareholders' wealth (e.g. Lin et al., 2012). Fraud costs tend to influence financial performance (Kellogg and Kellogg, 1991). Closed membership cooperatives can eliminate the problem of free-riders (Karantininis and Zago, 2001). Open membership cooperatives are not expected to produce high-quality products (Hovelaque et al., 2009; Mérel et al., 2009).

\section{- Member ownership-structural characteristics}

Older cooperatives may perform better (Bond, 2009), due to having more fixed assets and inventory turnover ratios (Harrington, 1993). Larger membership size may allow for more volume and reduce unit costs of e.g. inputs and transport (Boyd et al., 2007; Huang et al., 2013). However, larger cooperatives are more likely to face free-riding problems as a result of coordination issues (Olson, 1965). Monitoring members' commitments is more difficult and costly, and social sanctions are less effective for large memberships. In smaller cooperatives better information sharing and social sanctions could ensure cooperation (Hardin, 1982; Staatz, 1983). An alternative measure of size of a cooperative is the value of its assets. A cooperative with more assets may be more capable of providing services and having market power. Also both agency and supervisory costs may vary with size (Huang et al., 2013). Moreover, adequate capital is required for initial development and to guarantee long-term sustainability. When capital is limited, the cooperative will not be able to finance investments in assets (Ling, 2005), thereby limiting its performance. Traditional cooperatives, by their very nature, are equity bound due to solely member ownership, and therefore may be expected to rely more on debt financing making them more leveraged than firms. Higher leveraged cooperatives are, therefore, more likely to face financial stress (Gentzoglanis, 1997), leading to poor performance.

As cooperatives expand and diversify their business activities, the need to employ professionals to make strategic, tactical, and operational decisions increases (Cook, 1994; Hueth and Marcoul, 2009). The presence of professional employees makes cooperatives more viable and efficient and enables them to better serve the needs of their members (Adrian Jr and Green, 2001). The availability of infrastructure facilities, such as office and storage areas may contribute to the functioning of the cooperatives (Karami and RezaeiMoghaddam, 2005).

Unions or secondary cooperatives play an essential role in strengthening the performance of cooperatives (Krahnen and Schmidt, 1995) and are considered to be a source of competitive advantage (Wanyama et al., 2009). External support from the government and donors in the form of a revolving fund, farm machinery, and equipment can have a direct impact on the performance of cooperatives, particularly at the start of the cooperative (Rankin et al., 2007). In contrast, Karami and Rezaei-Moghaddam (2005) argue that too much external support would make them dependent on their financial sustainability endeavors. Business links with other cooperatives operating at the same organization level (e.g. among primary cooperatives) could help cooperatives to increase turnover and boost their competitive market position. Bengtsson and Kock (1999) argues that business relationships with other firms enable a company to gain access to products and other resources of importance for its business.

In this study, we search to understand which and how governance and structural characteristics influence the cooperatives' performance. The empirical evidence is based on data collected in the Tigray region, northern Ethiopia. Before turning to the methodology of data collection and econometric models, we introduce the specificities of agricultural cooperatives in Ethiopia.

\section{Agricultural cooperatives in Ethiopia}

Successive Ethiopian governments (from the Imperial period to the present government) gave recognition to the importance of cooperatives and made deliberate efforts to improve the organizations. During the Imperial era (1932-1974), cooperatives were primarily established to support the production of high-value agricultural products for export (Bernard et al., 2010). Success was however limited due to the presence of feudalistic land tenure systems. The subsequent military rule (1974-1991), which viewed agricultural cooperatives as key 
instruments to build a socialistic economy, pursued the cooperative agenda more aggressively. Membership was not voluntary and the organization was undemocratic by nature (Bernard et al., 2010).

Following the collapse of the socialist regime in 1991, cooperatives had become so unpopular and many disappeared quickly. They dissolved in such a disorderly manner that it created a lasting suspicion and distrust of cooperatives, which still haunts the cooperatives' reputation until today (Emana, 2009). In an attempt for a fresh start, successive governments over the last two decades have tried to rectify the flaws and practices made possible by earlier laws (FCA, 2015). The Ethiopian Cooperative Proclamation provides for cooperatives to be established in different sectors/subsectors. The Proclamation also stresses the formation of cooperatives along the principle of one-cooperative-type-per-village. Each type of cooperative must operate based on its registered activity and it cannot compete with other cooperative types. Hence, the cooperative types considered in this paper are exclusive. Over time, the number and diversity of cooperatives increased rapidly. According to the survey conducted by the Agricultural Transformation Agency, the cooperative sector in Ethiopia grew by about $87 \%$ over the last five years. The number of cooperatives grew notably in Tigray, Oromia, and Somalia regional states (Bernard et al., 2013). Recent data from the Federal Cooperative Agency estimated the number of cooperatives at 74,000 with 14 million members and a capital of 5.4 billion ETB (FCA, 2015).

According to the Tigray Cooperative Promotion Agency, the number of registered cooperatives in the region is estimated at 4,265, which include livestock, natural resource, multipurpose, and service cooperatives. Livestock cooperatives (about $30 \%$ of the total), include: (a) beekeeping cooperatives engaged in production of honey from traditional and modern beehives and sell their produce either to a union or retailers; (b) beef-cattle, sheep and goat fattening cooperatives, which collectively purchase young and less conditioned livestock, feed them for three months and collectively sell them at spot markets; and (c) dairy cooperatives, which collect milk from members who own improved hybrid cows and directly sell it to urban consumers. Many livestock cooperatives are emerging in the rural areas as a government solution to contribute to the livelihoods of landless and unemployed rural youth who have completed vocational school. The second type are the natural resource cooperatives $(24 \%)$, which include irrigation and forestry cooperatives. Irrigation cooperatives collectively engage in construction and maintenance of river diversion canals and motor pumps for common use of water to members. They are also involved in the production and marketing of fruits and vegetables using irrigation water. Forestry cooperatives are organized by farmers for joint nature conservation and sustainable use of forest resources for example by seedling multiplication and the harvesting of frankincense and other natural gums and resins. A third type are the multipurpose cooperatives (16\%) that offer a range of services to members who own land for cultivation. The services include, for example: (a) providing farm inputs such as fertilizers, seeds, and farm implements; (b) facilitating the aggregation of products such as sesame, sorghum, and maize; and (c) providing services such as farm machinery, a grinding mill, and storage. The remaining 30\% are service cooperatives that offer savings and credit services. Their aggregate membership reached over 1.5 million people and the value of their pooled capital is estimated at more than one billion ETB (36.8 million USD) (TCPA, 2017). The agricultural cooperatives considered in this study include three of the four types mentioned above, namely livestock cooperatives, natural resource cooperatives, and multipurpose cooperatives.

\section{Methods}

\subsection{Study area and sampling technique}

Agriculture is the most important economic activity in the Tigray region and the sector contributes about $40 \%$ of the regional GDP. The cooperative sector is strong in the region (Bernard et al., 2013) and it attracts a large membership (estimated at $35 \%$ of the population) (TCPA, 2017). We conducted a cooperative level survey in all four zones of the region except the urbanizing Mekelle special zone from April to August 2017. A three-stage random sampling was used to select 511 agricultural cooperatives. In the first stage, we randomly selected three weredas (districts) from four zones (Figure 1). In the second stage, a total of 249 tabias 
(villages) were randomly selected from each wereda, proportionately considering the number and type of cooperatives operating (Table 1). In the third stage, using the probability proportion to size technique, we selected 511 agricultural cooperatives from those 249 tabias. The sample includes cooperatives involved in agricultural production and marketing which accounts for $65 \%$ of the entire target agricultural cooperatives. Service cooperatives that provide savings and credit services were excluded.

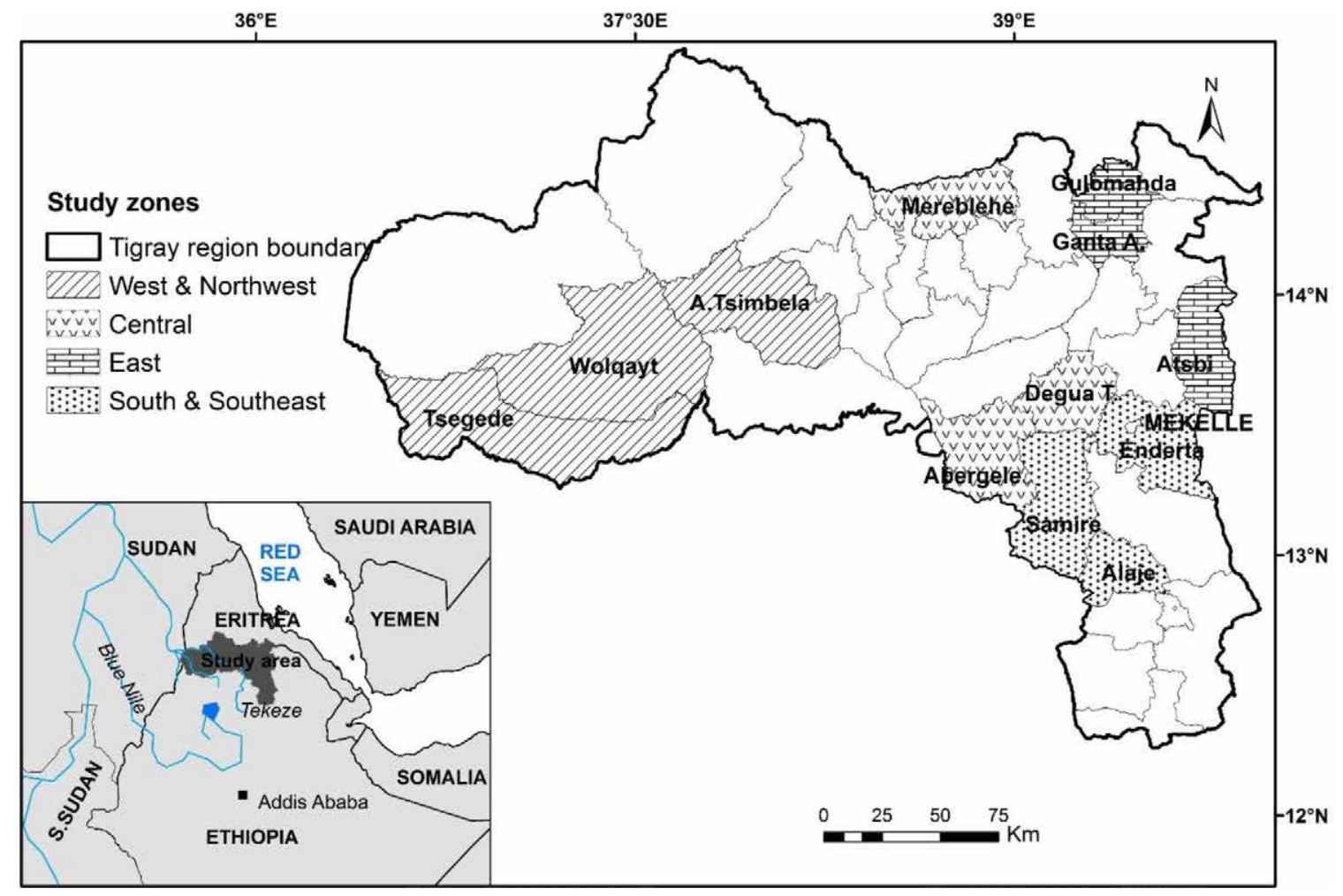

Figure 1. Study area in the Tigray Region, Ethiopia.

Table 1. Distribution of sampled agricultural cooperatives across zones and weredas.

\begin{tabular}{llcc}
\hline Zone & Wereda selected & $\begin{array}{l}\text { Number of selected } \\
\text { tabias }\end{array}$ & $\begin{array}{l}\text { Number of selected } \\
\text { cooperatives }\end{array}$ \\
\hline Eastern & Atsbi Wenberta & 33 & 43 \\
& Ganta Afeshum & 16 & 40 \\
\multirow{4}{*}{ Central } & Gulomekeda & 25 & 51 \\
& Abergele & 22 & 32 \\
\multirow{3}{*}{ South and southeastern } & 17 & 64 \\
& Degua Tembien & 14 & 22 \\
& MerebLeke & 16 & 41 \\
West and northwestern & Alaje & 24 & 53 \\
& Enderta & 20 & 41 \\
& Samre & 12 & 25 \\
& AsgedeTsimbla & 25 & 57 \\
\hline Total & Tsegede & 25 & 42 \\
\hline
\end{tabular}


A structured questionnaire was used to collect data on the chairperson characteristics, service provision, production and marketing, governance and performance, dividend, and tabia-level variables. In addition to the structured questionnaire, an extensive review of readily available cooperative bylaws, past audit reports, cooperative periodic activity reports including financial statements and strategic plan documents was made. The questionnaire was pre-tested in September 2016 on 65 randomly selected cooperatives (data are not included in the analysis). A group of trained enumerators and supervisors, fluent in Tigrigna, interviewed the chairpersons of the cooperatives. In the case of absence of the chairperson, we interviewed the vice-chairpersons (which was done in $18 \%$ of the sample). All interviews were held at the offices of the respective cooperatives.

\subsection{Calculation of the outcome variables}

To calculate the total sales, six different cooperative income sources are considered, namely: (1) sales of farm inputs to members and non-members (fertilizers, pesticides, herbicides, and seeds); (2) sales of farm implements (sickle, motor pump, treadle pump); (3) sales of members' farm produce (mainly cereals, sesame, fruits and vegetables); (4) sales of livestock and livestock products (like honey, milk, cattle, sheep, goat); (5) NRCs sales include sales of fruits and vegetables, nursery seedling, frankincense, and other gums and resins, fuelwood, grass forage for livestock, and grass; and (6) sales of consumer goods (sugar, cooking oil, coffee). The latter may not be common in other regions, but is a key activity of multipurpose cooperatives in Ethiopia, next to providing agricultural services.

Gross profit is calculated as the total operating revenue for each of the cooperatives minus the total cost of goods sold, which includes the cost of the input or material used in producing or supplying the goods along with the direct labor cost used to produce or supply the goods, and transport costs. The regulator requires cooperatives to set aside $30 \%$ of the net profits (after deducting the overhead costs and interest payment from gross profit) into statutory reserves and the cooperative pays out the remaining $70 \%$ to members as dividend in proportion to their investment in shares and transaction volume. The dividend policy varies from cooperative to cooperative.

\subsection{Econometric model specification}

\section{- An exploratory ordinary least squares regression model on cooperatives performance}

The outcome variables are measured in total value in ETB (Ethiopian currency) and are considered for the year 2015/2016. Except for the gross profit, cooperative sales and sales per member are specified in logarithmic terms. An exploratory Ordinary Least Squares regression model (OLS) was used to identify the drivers of performance in sales and sales per member. The OLS model is specified as follows:

$$
Y_{j}=\alpha_{0}+C_{j}^{\prime} \alpha_{1}+I_{j}^{\prime} \alpha_{2}+G_{j}^{\prime} \alpha_{3}+E_{j}^{\prime} \alpha_{4}+L_{j}^{\prime} \alpha_{5}+T_{j}^{\prime} \alpha_{6}+\varepsilon_{j}
$$

where $Y_{j}$ is an outcome variable, including sales and sales per member of the $j$-th cooperative; $C_{j}$ is a vector of characteristics of the chairperson of the $j$-th cooperative; $I_{j}$ is a vector of cooperative-specific institutional characteristics of the $j$-th cooperative; $G_{j}$ is a vector of governance characteristics in the $j$-th cooperative; $E_{j}$ a vector of external linkages and support of the $j$-th cooperative; $L_{j}$ is a vector of dummies representing four cooperative locations related to the $j$-th cooperative; and $T_{j}$ is a vector of dummies representing three cooperative types (multipurpose, livestock, natural resource); $\varepsilon_{\mathrm{j}}$ denotes error terms, and $\alpha$ 's are vectors of parameters to be estimated. See Supplementary Table S1 for an overview of the descriptions of variables. 


\section{- A Heckman selection model for analyzing determinants of profit performance}

The outcome variable profit was taken from the financial statements of the audited cooperatives. In the Ethiopian context, for a cooperative to be declared as profitable or otherwise, it should be audited (Benson, 2014). For a non-audited cooperative, profit is not registered. Financial auditing is carried out primarily to monitor whether the agents of the member-owners (the management staff) and board of directors have utilized the financial resources to serve the interests of the members (Pozzabon et al., 2012). Regular financial audits help to ensure that directors and managers are made accountable for the use of the financial resources based on the interests of the member-owners. Audits contribute to predictability, which helps to respond to changing circumstances that challenge the cooperatives' transparency. It also serves as a means of controlling corrupt practices and to build trust among members and participation to maximize the benefits of cooperative membership (Benson, 2014).

In the study area, cooperatives get auditing services by the government-run cooperative promotion agency. However, because of a shortage of government auditors, due mainly to poor incentive packages and high staff turnover (Benson, 2014), not all cooperatives get this service. Cooperatives are selected for audit in a non-random way, either systematically based on some criteria, or the cooperatives themselves ask for the service. The agency uses informal ways to prioritize which cooperatives should be audited based on the following criteria: (a) the presence of conflict and fraud; (b) the presence of multiple products with large sales turnover; (c) a number of loan defaulters; or (d) a plan to pay dividends to members. As a result, about $44 \%$ of the surveyed cooperatives were not audited since their inception. In this case, the audited cooperatives may not constitute a random sample of the population of all cooperatives when analyzing profit. To control for the potential bias due to the selectivity problem that arises because of the non-random auditing, we use a Heckman selection model (Heckman, 1979) with a first step selection (audit) equation, and a second step outcome (profit) equation specified as follows:

$$
P_{j}^{*}=\beta_{0}+C_{j}^{\prime} \beta_{1}+I_{j}^{\prime} \beta_{2}+G_{j}^{\prime} \beta_{3}+E_{j}^{\prime} \beta_{4}+L_{j}^{\prime} \beta_{5}+T_{j}^{\prime} \beta_{6}+v_{j}
$$

Where $P_{j}^{*}$ denotes a latent variable for the profit of the $\mathrm{j}$-th cooperative; $v_{j}$ is a random error term associated with the outcome variable; others are as defined above. The profit $P_{j}^{*}$ is not observed for a cooperative that has not been audited. Following Verbeek (2008), we model the likelihood of an audit of the j-th cooperative (selection equation) as:

$$
H_{j}^{*}=\gamma_{0}+C_{j}^{\prime} \gamma_{1}+I_{j}^{\prime} \gamma_{2}+G_{j}^{\prime} \gamma_{3}+E_{j}^{\prime} \gamma_{4}+L_{j}^{\prime} \gamma_{5}+T_{j}^{\prime} \gamma_{6}+S_{j}^{\prime} \gamma_{7}+u_{j}
$$

Besides including the same variables as in Equation 2, Equation 3 has a vector of identification variables $S_{j}$. The relationship between the outcome variable $Y_{j}$ and the selection variable $H_{j}$ is given as follows:

$$
H_{\mathrm{j}}=\left\{\begin{array}{l}
1 \text { if } H_{j}^{*}>0 \\
0 \text { if } H_{j}^{*} \leq 0
\end{array}\right\}
$$

and

$$
P_{\mathrm{j}}=\left\{\begin{array}{cc}
P_{j}^{*} & \text { if } H_{\mathrm{j}}=1 \\
\text { unobserved if } H_{\mathrm{j}}=0
\end{array}\right\}
$$

Where $P_{j}$ denotes cooperative j's actual profit. The binary variable $H_{j}$ indicates whether the $\mathrm{j}$-th cooperative is audited $\left(H_{j}=1\right)$ or not $\left(H_{j}=0\right)$. The error terms $v_{j}$ and $u_{j}$ are assumed to be bivariate normally distributed with a zero expected value, variances of $\sigma^{2}{ }_{v}$ and $\sigma^{2}{ }_{u}$, respectively, and a covariance of $\sigma_{v u}$. The conditional expected profit, given that a cooperative is audited, is given by: 


$$
\begin{aligned}
E\left[P_{\mathrm{j}} / H_{\mathrm{j}}=1\right]= & C_{j}^{\prime} \beta_{1}+I_{j}^{\prime} \beta_{2}+G_{j}^{\prime} \beta_{3}+E_{j}^{\prime} \beta_{4}+L_{j}^{\prime} \beta_{5}+T_{j}^{\prime} \beta_{6}+E\left[v_{\mathrm{j}} / H_{\mathrm{j}}=1\right] \\
= & C_{j}^{\prime} \beta_{1}+I_{j}^{\prime} \beta_{2}+G_{j}^{\prime} \beta_{3}+E_{j}^{\prime} \beta_{4}+L_{j}^{\prime} \beta_{5}+T_{j}^{\prime} \beta_{6}+E\left(v_{\mathrm{j}} / u_{\mathrm{j}}>-\left[C_{j}^{\prime} \gamma_{1}+I_{j}^{\prime} \gamma_{2}\right.\right. \\
& \left.\left.+G_{j}^{\prime} \gamma_{3}+E_{j}^{\prime} \gamma_{4}+L_{j}^{\prime} \gamma_{5}+T_{j}^{\prime} \gamma_{6}+S_{j}^{\prime} \gamma_{7}\right]\right) \\
= & C_{j}^{\prime} \beta_{1}+I_{j}^{\prime} \beta_{2}+G_{j}^{\prime} \beta_{3}+E_{j}^{\prime} \beta_{4}+L_{j}^{\prime} \beta_{5}+T_{j}^{\prime} \beta_{6} \\
& +\left(\frac{\sigma_{v u}}{\sigma_{u}^{2}}\right) E\left(v_{\mathrm{j}} / u_{\mathrm{j}}>-\left[C_{j}^{\prime} \gamma_{1}+I_{j}^{\prime} \gamma_{2}+G_{j}^{\prime} \gamma_{3}+E_{j}^{\prime} \gamma_{4}+L_{j}^{\prime} \gamma_{5}+T_{j}^{\prime} \gamma_{6}+S_{j}^{\prime} \gamma_{7}\right]\right) \\
= & C_{j}^{\prime} \beta_{1}+I_{j}^{\prime} \beta_{2}+G_{j}^{\prime} \beta_{3}+E_{j}^{\prime} \beta_{4}+L_{j}^{\prime} \beta_{5}+T_{j}^{\prime} \beta_{6} \\
& +\sigma_{v u} \frac{\phi\left(C_{j}^{\prime} \gamma_{1}+I_{j}^{\prime} \gamma_{2}+G_{j}^{\prime} \gamma_{3}+E_{j}^{\prime} \gamma_{4}+L_{j}^{\prime} \gamma_{5}+T_{j}^{\prime} \gamma_{6}+S_{j}^{\prime} \gamma_{7}\right)}{\Phi\left(C_{j}^{\prime} \gamma_{1}+I_{j}^{\prime} \gamma_{2}+G_{j}^{\prime} \gamma_{3}+E_{j}^{\prime} \gamma_{4}+L_{j}^{\prime} \gamma_{5}+T_{j}^{\prime} \gamma_{6}+S_{j}^{\prime} \gamma_{7}\right)}
\end{aligned}
$$

where the last equality assumes $\sigma_{u}^{2}=1$ (a normalization restriction) and the expression for the expectation of a truncated standard normal distribution.

The identification variables $S_{j}$ in the audit Equation 3 were selected based on previous related literature and on our field knowledge on the factors that determine the probability of whether a cooperative is audited or not. The following variables are considered important: (a) total capital; cooperatives with an adequate capital base are more likely to receive audit services; (b) leverage is included to capture the impact of financial debt. It is measured by the ratio of total liabilities to total assets. Regulations set a limit on cooperative borrowing, which will depend on the level of capital reserve. Hence, we expect cooperatives with more debts to be more likely to be selected for audit; (c) audit committee is a dummy that takes value 1 if the cooperative has such committee installed. These committees are expected to conduct internal audits and inspect the documents of the cooperative at least once a month; hence, cooperatives are more likely to receive an audit if they are known to have an audit committee; (d) financial statement is a dummy specifying whether or not the cooperative had prepared financial statements. We assume that cooperatives are more likely to be audited if they can provide financial statements such as income statements, balance sheets, cash and nongrants statement; (e) financial fraud is a dummy that indicates whether financial fraud has occurred in the cooperative since its inception. Regulations stipulate that when a majority of the board members or more than one-third of the total members requests to detect fraud, the government will assign auditors to inspect the financial records. Hence, cooperatives that faced financial fraud are more likely to be selected for audit; (f) access to credit is a dummy indicating whether a cooperative has access to credit. We expect that credit access eases cooperative liquidity constraints which, in turn, may increase the propensity to provide more services to their members. Hence, cooperatives are more likely to receive audits if they are known to have access to external funds; and (g) distance to the cooperative office measured as the distance from the village where the cooperative is located to the wereda cooperative office in minutes is included because we expect that cooperatives close to the government audit office are more likely to be audited.

\subsection{Descriptive statistics}

Table 2 gives a descriptive summary of the variables of interest in this research. The data confirm that cooperatives in the sample were highly heterogeneous. The annual sales value of the cooperatives ranges from 560 to a maximum of 12.1 million ETB (444,843 USD). The standard deviations of the gross profits were equally large. Interesting to note is that $44 \%$ of the cooperatives were not audited since their inception, which is partly attributed to a shortage of government auditors due to the poor incentive packages and high staff turnover (Benson, 2014). As a consequence, these cooperatives were not in a position to pay dividends to their members. Secondly, because of the delay in the audits, cooperatives fail to get services (e.g. credit, fertilizer) from their respective unions, who demand for audit reports in order to reduce the risks of default.

The cooperatives also differ much in their characteristics. Chairpersons have served on average of 3.5 years. Some had been serving for quite a long time which is actually not allowed by the Cooperative Proclamation that limits the terms of office to three years with a maximum of two consecutive terms. During the survey, some chairpersons were found to have served more than one term without consent of the general assembly. Others were not replaced since the start of the cooperative. Most of the cooperatives visited were established 
between 2009 and 2016. A number of cooperatives were started as part of the Rural Financial Intermediation program or by initiative of NGOs. The former program provided credit to poor households to support selfemployment and small enterprise development and was financed by IFAD, the African Development Bank and the Ethiopia government; it has sparked the formation of a large number of primary cooperatives in rural areas. Also, membership varies. Noteworthy is that the Cooperative Proclamation requires a primary cooperative to be dissolved if its membership falls below ten. However, we still find cooperatives with fewer members. About $52 \%$ of the cooperatives have an office, of which about $40 \%$ owned it and the other cooperatives either shared it with the village agricultural and rural development offices or rented it.

According to the Cooperative Proclamation, each cooperative should have a board of directors, and five other sub-committees, such as those responsible for control, credit, savings, training and education, and auditing. Not all cooperatives visited had these committees installed. Results also indicate that women remain under-represented in the governance structures of their cooperatives. Few women serve on a board, and only a few cooperatives had a woman director, while women make up on average $45 \%$ of the membership. Few cooperatives were found to compensate their board members. A significant number of cooperatives experienced conflicts in the past years among members, and a fifth of the respondents mentioned that financial fraud was committed in their cooperatives.

Although the Cooperative Proclamation promotes that cooperatives are open to all persons who could use the cooperative services and assume membership responsibilities, we find 'closed' cooperatives in beekeeping, irrigation, and livestock. Several of these cooperatives were established by programs of the regional government of Tigray to organize landless and unemployed rural households in these cooperatives in order to support their livelihoods. Depending on the type of cooperative, membership was limited to 15 to 25 persons. Most of the closed cooperatives were given access to area enclosures, forestlands and mountains for joint honey production, livestock fattening and seed multiplication. The membership limit was set by the local government. When a member would withdraw or terminate membership, closed cooperatives create a barrier to entry for prospective members by asking to pay a lump sum to buy themselves into the cooperative. This money is meant to compensate for the labor, time, and resources the current members invested so far in the cooperative.

As mentioned above, some cooperatives received support when they were initiated. About half of the cooperatives had a business link with other cooperatives and/or are member of a union. Such membership to a union is not voluntary although there is no uniformity in the eligibility criteria. Unions are second-tier organizations established by two or more primary cooperatives having similar objectives and perform similar functions. In some cases, cooperatives are forced to join unions through a government-led cooperative agency in order for them to be financially viable and more efficient in their operations through accessing services, such as the supply of farm inputs, consumer goods, output aggregation, value addition through processing, and linking cooperatives to domestic and international buyers. Unions also provide credit, and specialized training (such as bookkeeping and auditing) to member cooperatives and assist them to develop annual strategic plans. Finally, most cooperatives were located in remote rural areas and most households lived in scattered rural communities with a lack of access to transport services.

Table 3 compares the performance of three groups of cooperatives, namely: (1) multipurpose cooperatives (MPCs); (2) livestock cooperatives (LVCs), and (3) natural resource cooperatives (NRCs), which were sampled in almost equal numbers. Noteworthy is again the wide variability across the cooperatives. The highest sales value and gross profit realized were measured among multipurpose cooperatives. This does not come as a surprise given their larger operational area and extensive service portfolio which gives them an opportunity to enlarge membership. 
Table 2. Descriptive statistics of the variables included in the models. ${ }^{1}$

\begin{tabular}{|c|c|c|c|c|c|}
\hline Variables (unit) & $\mathbf{n}$ & Mean & Std. dev. & Minimum & Maximum \\
\hline \multicolumn{6}{|l|}{ Dependent variables } \\
\hline Total sales (1000 ETB) & 511 & 657.39 & $1,545.13$ & 0.56 & $12,068.12$ \\
\hline Sales per member (1000 ETB) & 504 & 3.22 & 9.08 & 0.01 & 94.08 \\
\hline Gross profit (1000 ETB) & 284 & 310.71 & $2,453.54$ & $-2,682.49$ & $44,206.10$ \\
\hline Audited (yes $=1)$ & 511 & 0.556 & 0.498 & 0.00 & 1.00 \\
\hline \multicolumn{6}{|l|}{ Independent variables } \\
\hline \multicolumn{6}{|l|}{ Chairperson characteristics } \\
\hline Chairperson education (years) & 511 & 5.857 & 2.797 & 0.00 & 13.00 \\
\hline Chairperson working experience (years) & 511 & 3.543 & 2.961 & 0.00 & 20.00 \\
\hline \multicolumn{6}{|l|}{ Institutional characteristics } \\
\hline Age of cooperative (years) & 504 & 8.685 & 7.423 & 0.500 & 38.00 \\
\hline Membership size (number) & 504 & 380.62 & 551.16 & 4.00 & $2,550.00$ \\
\hline Cooperative size in assets (1000 ETB) & 511 & 692.25 & $4,720.99$ & 1.50 & $1,011.00$ \\
\hline Total capital (1000 ETB) & 511 & 124.93 & $2,014.55$ & $1,343.57$ & $44,206.30$ \\
\hline Leverage (number) & 454 & 0.148 & 0.629 & 0.00 & 7.510 \\
\hline Presence of employees (yes $=1$ ) & 510 & 0.686 & 0.464 & 0.00 & 1.00 \\
\hline Cooperative office $($ yes $=1)$ & 511 & 0.517 & 0.500 & 0.00 & 1.00 \\
\hline \multicolumn{6}{|l|}{ Governance characteristics } \\
\hline Number of cooperative committees & 511 & 4.523 & 1.246 & 1.00 & 8.00 \\
\hline Women directors (number) & 511 & 1.141 & 1.106 & 0.00 & 5.00 \\
\hline Board education (years) & 511 & 5.787 & 2.087 & 0.00 & 11.00 \\
\hline Board cash compensation (yes $=1$ ) & 511 & 0.076 & 0.266 & 0.00 & 1.00 \\
\hline Presence of audit committee (yes $=1$ ) & 505 & 0.752 & 0.432 & 0.00 & 1.00 \\
\hline Prepared financial statement (yes $=1$ ) & 511 & 0.701 & 0.458 & 0.00 & 1.00 \\
\hline Experiences of conflicts (yes $=1$ ) & 510 & 0.429 & 0.495 & 0.00 & 1.00 \\
\hline Presences of financial fraud (yes $=1$ ) & 510 & 0.216 & 0.412 & 0.00 & 1.00 \\
\hline Membership policy (closed $=1$ ) & 510 & 0.300 & 0.459 & 0.00 & 1.00 \\
\hline \multicolumn{6}{|l|}{ External linkages and support } \\
\hline Received help during set up (yes $=1$ ) & 506 & 0.751 & 0.433 & 0.00 & 1.00 \\
\hline Business links with other coops (yes $=1$ ) & 511 & 0.524 & 0.500 & 0.00 & 1.00 \\
\hline Access to credit $(y e s=1)$ & 511 & 0.652 & 0.447 & 0.00 & 1.00 \\
\hline Union membership (yes $=1$ ) & 510 & 0.475 & 0.500 & 0.00 & 1.00 \\
\hline \multicolumn{6}{|l|}{ Village level characteristics } \\
\hline Distance to cooperative office (minutes) & 499 & 27.99 & 29.101 & 1.00 & 360.00 \\
\hline
\end{tabular}

Table 3. Cooperatives performance measured by sales value and profit. ${ }^{1}$

\begin{tabular}{|c|c|c|c|c|}
\hline \multirow[t]{2}{*}{ Type of cooperatives } & \multirow[t]{2}{*}{ Total cooperatives } & \multirow[t]{2}{*}{ Total members } & \multicolumn{2}{|c|}{ Mean value (1000 ETB) } \\
\hline & & & Sales value & Gross profit \\
\hline $\mathrm{MPCs}^{2}$ & 180 & 180,726 & $1,383.23(2,042.21)$ & $625.99(3,735.69)$ \\
\hline $\mathrm{LVCs}^{2}$ & 201 & 5,379 & $149.19(766.06)$ & $64.59(305.28)$ \\
\hline $\mathrm{NRCs}^{2}$ & 130 & 8,023 & $235.85(904.85)$ & $122.03(736.92)$ \\
\hline Total & 511 & & $605.92(1,493.79)$ & $303.549(2,413.12)$ \\
\hline F-stat & & & $44.14 * * *$ & $2.38^{*}$ \\
\hline Pairwise contrast ${ }^{\mathrm{a}}$ & & & MPC > LVC, NRC & - \\
\hline
\end{tabular}




\section{Results and discussion}

\subsection{Drivers of sales}

Table 4 gives the estimation results of the OLS models on cooperative sales (total and per member) using the explanatory variables introduced above including cooperative and zonal fixed effect dummies. The estimators in the models with cooperative and/or zone dummies are within-group estimators, that control for unobservable cooperative type and/or zonal fixed effects. Estimation results in all models are moderately robust despite a considerable difference in the value of the R-squared (between 0.12 and 0.42 ). The correlation statistics and variance inflation factor (Pindyck and Rubinfeld, 1998) tests fail to indicate potential multicollinearity problems (tables available upon request by the author). To test the potential endogeneity of union membership and cooperative size to sales as the dependent variable, we estimated alternative two-stage least square (2SLS) instrumental variable (IV) models. The Durbin-Wu-Hausman test statistics of these model indicate

Table 4. Determinants of log transformed sales (Ordinary Least Squares regression model). ${ }^{1,2}$

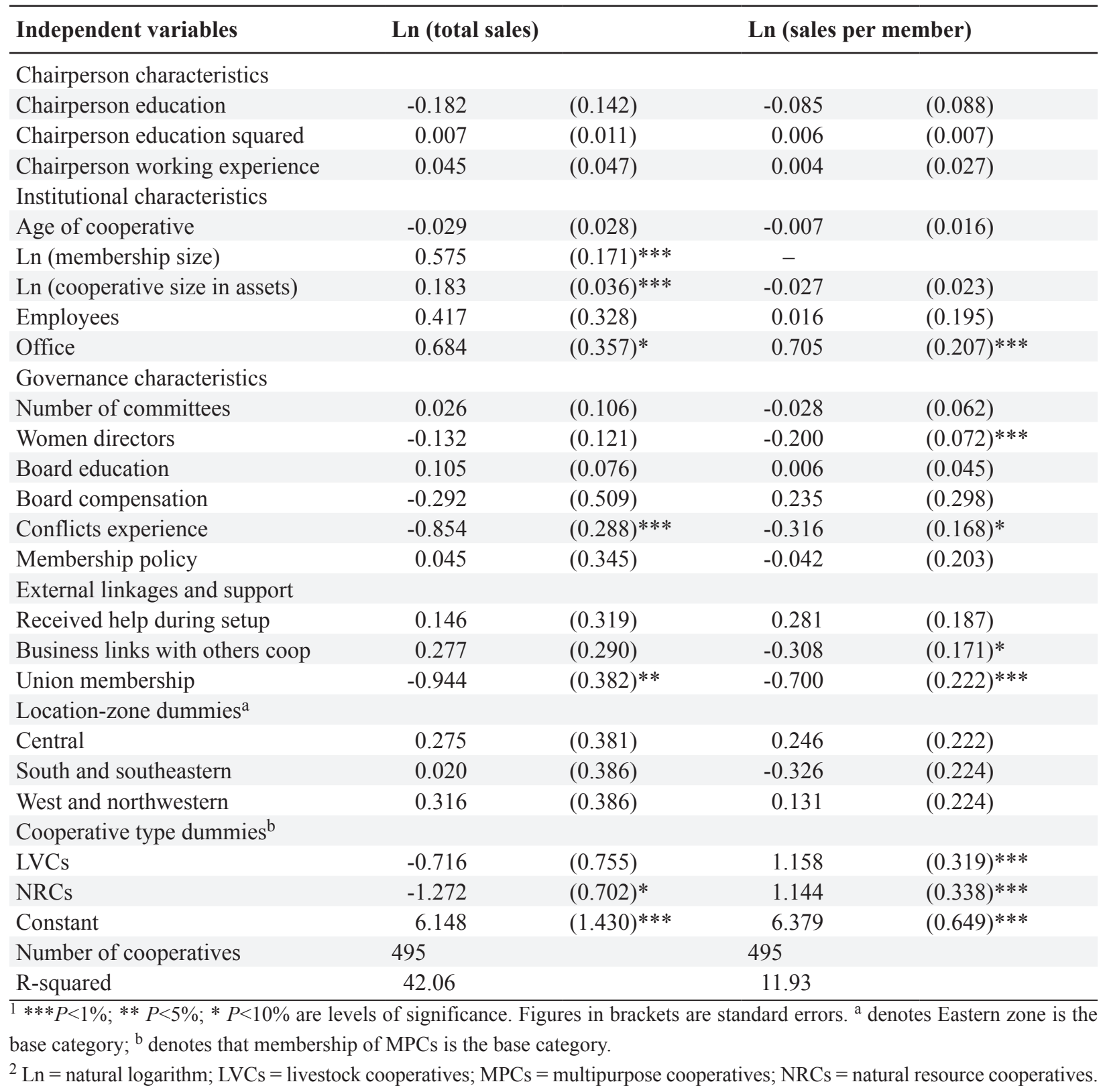


no evidence for the endogeneity of union membership $\left(\mathrm{F}_{1}, 475=2.609, P=0.107\right)$ and cooperative size $\left(\mathrm{F}_{1}, 54=0.122, P=0.882\right)^{1}$. The Sargan statistics for over-identification restriction are insignificant for the IVs bank account and distance to the union office $\left(\mathrm{Chi}^{2}=0.010 ; P=0.920\right)$, and lagged assets $\left(\mathrm{Chi}^{2}=0.053\right.$; $P=0.818$ ), confirming that these IVs used in the model are valid and are not correlated with the error term of the structural Equation 1. While we cannot fully exclude a potential effect of endogeneity on our results, we prefer to present the results of the OLS model. However, the estimation results must be interpreted cautiously.

\subsection{Determinants of audits and profits}

We estimate the OLS and Heckman models presented in Table 5 using the same vectors of explanatory variables specified in Equation 1. The OLS model and Heckman outcome equation estimate the determinants of profit while the selection equation measures the factors affecting the likelihood of being audited. The model statistics indicate that the association between the error terms of the outcome and selection equations (rho) is statistically different from zero. The likelihood ratio (LR) test of correlation between the error terms of the two equations is significant. The confidence interval of the Lambda values does not include the number zero. This confirms the presence of selectivity problems in the OLS model, which justifies the use of the Heckman selection model.

The results of the selection equation suggest that mainly the older cooperatives and those with more members were audited. Cooperatives with less capital and those located close to the wereda cooperative office were more likely to have been audited. Results also suggest that the cooperatives with relatively more women in their boards, these that had an audit committee, that were able to provide financial statements and had business links with other cooperatives were more likely to have been audited. The results also highlight that access to credit positively influenced the likelihood of audit. In Ethiopia, cooperatives fail to access credit from banks due to collateral shortages. Even in donor financing programs, the credit requests may not be approved unless the agency acts as a security guarantor. Finally, cooperatives located further from the wereda cooperative office were less likely to be audited due to their remoteness and the generally poor state of the infrastructure. LVCs and NRCs were more likely to be audited compared to MPCs.

\section{- Institutional characteristics}

The age of the cooperative seems not important for sales nor profit, but membership does. Membership size is positively associated with both sales and profit. This finding is consistent with Karami and RezaeiMoghaddam (2005), Liang et al. (2015) and Ragasa and Golan (2014). Also, total assets of a cooperative are positively associated with total sales and profit, but not significant for sales per member. In Ethiopian cooperatives, these assets reflect the value of what the cooperatives received during their initial formation through donation and no substantial change in assets is usually observed (Bernard and Spielman, 2009). Many Ethiopian cooperatives were initiated and formed through top-down interventions by the government or NGOs (Francesconi and Ruben, 2008). This external financial and material assistance attracts members to join cooperatives and is often used to initiate cooperative service operations. While the number of employees seems not to matter for sales, having an office is positively related to sales.

\section{- Governance characteristics}

We find little evidence that associates the chairperson's characteristics with the cooperative's performance. This is consistent with Bond (2009), who finds an insignificant relationship between the financial performance of US agricultural cooperatives and the directors' characteristics. One result stands out; the coefficient of education of the chairperson was not significant in the sales model, but negative in the profit model. The

\footnotetext{
${ }_{1}^{1}$ To test the endogeneity of the model, a three-step procedure was followed. In step one, we estimated two-stage least square (2SLS) instrumental variable (IV) models for each endogenous variable separately using its respective instrument. In the second step, the 'estat overid' command was applied in STATA to test the over-identification restriction (Sargan-test) as well as the validity of the instrumental variables used. In step three, the 'estat endogenous' command was applied to test if the variables union membership and cooperative size are endogenous (Wu-Hausman F-statistics).
} 
Table 5. Determinants of cooperatives profit and auditing (Ordinary Least Squares regression (OLS) and Heckman model). ${ }^{1}$

\begin{tabular}{|c|c|c|c|c|c|c|}
\hline \multirow{3}{*}{$\begin{array}{l}\text { Independent variables } \\
\text { Chairperson characteristics } \\
\end{array}$} & \multirow{2}{*}{\multicolumn{2}{|c|}{ OLS profit Equation 1}} & \multicolumn{4}{|c|}{ Heckman model } \\
\hline & & & \multicolumn{2}{|c|}{ Profit Equation 2} & \multicolumn{2}{|c|}{ Audit Equation 3} \\
\hline & & & & & & \\
\hline Chairperson education & -131.083 & $(59.955)^{* *}$ & -123.162 & $(63.869)^{*}$ & -0.069 & $(0.084)$ \\
\hline Chairperson education squared & 8.704 & $(4.582)^{*}$ & 7.336 & $(4.814)$ & 0.005 & $(0.006)$ \\
\hline Chairperson working experience & -10.766 & $(17.862)$ & -16.415 & $(18.885)$ & 0.003 & $(0.032)$ \\
\hline \multicolumn{7}{|l|}{ Institutional characteristics } \\
\hline Age of cooperative & -1.278 & $(10.349)$ & -10.809 & $(11.430)$ & 0.116 & $(0.023)^{* * *}$ \\
\hline $\operatorname{Ln}^{2}$ (membership size) & 134.393 & $(69.375)^{*}$ & 147.768 & $(85.864)^{*}$ & 0.343 & $(0.113)^{* * *}$ \\
\hline $\mathrm{Ln}^{2}$ (cooperative size in assets) & 13.334 & $(15.681)$ & 118.602 & $(50.277)^{* *}$ & - & \\
\hline $\operatorname{Ln}^{2}$ (total capital) & - & & - & & -0.074 & $(0.023)^{* * *}$ \\
\hline Leverage & - & & - & & 0.052 & $(0.197)$ \\
\hline Employees & -289.495 & $(177.665)$ & -367.645 & $(192.426)^{*}$ & 0.050 & $(0.190)$ \\
\hline Office & 236.681 & $(170.912)$ & 26.911 & $(196.108)$ & 0.345 & $(0.202)^{*}$ \\
\hline \multicolumn{7}{|l|}{ Governance characteristics } \\
\hline Number of committees & -28.189 & $(47.596)$ & -41.169 & $(50.850)$ & -0.011 & $(0.061)$ \\
\hline Women directors & -117.497 & $(51.405)^{* *}$ & -161.817 & $(58.462)^{* * *}$ & 0.169 & $(0.078)^{* *}$ \\
\hline Board education & 40.341 & $(32.897)$ & 42.879 & $(35.955)$ & 0.078 & $(0.046)^{*}$ \\
\hline Board compensation & 110.957 & $(177.685)$ & 54.219 & $(193.305)^{* *}$ & 0.344 & $(0.431)$ \\
\hline Audit committee & - & & - & & 0.286 & $(0.198)^{*}$ \\
\hline Financial statement & - & & - & & 0.407 & $(0.199)^{* *}$ \\
\hline Conflicts experience & -201.979 & $(122.994)$ & 252.912 & $(129.903)^{*}$ & -0.240 & $(0.179)$ \\
\hline Financial fraud & - & & - & & 0.222 & $(0.224)$ \\
\hline Membership policy & -186.992 & $(178.767)$ & -115.609 & $(192.086)$ & -0.066 & $(0.196)$ \\
\hline \multicolumn{7}{|l|}{ External linkages and support } \\
\hline Received help during setup & -3.319 & $(147.609)$ & -6.346 & $(160.304)$ & - & \\
\hline Business links with others coop & 205.784 & $(129.849)$ & 179.895 & $(142.856)^{*}$ & 0.470 & $(0.177)^{* * *}$ \\
\hline Union membership & -222.049 & $(185.839)$ & -414.018 & $(208.278)^{* *}$ & 0.134 & $(0.226)$ \\
\hline Access to credit & - & & - & & 0.329 & $(0.180)^{*}$ \\
\hline \multicolumn{7}{|l|}{ Village level characteristics } \\
\hline Distance to coop office & - & & - & & -0.011 & $(0.004)^{* * *}$ \\
\hline \multicolumn{7}{|l|}{ Location-zone dummies $^{\mathrm{a}}$} \\
\hline Central & -238.015 & $(171.318)$ & -155.105 & $(185.884)$ & -0.704 & $(0.238)^{* * *}$ \\
\hline South and southeastern & -210.895 & $(163.565)$ & -242.588 & $(183.629)$ & -0.620 & $(0.260)^{* *}$ \\
\hline West and northwestern & 367.849 & $(160.082)^{* *}$ & 386.000 & $(173.921)^{* *}$ & -0.013 & $(0.240)$ \\
\hline \multicolumn{7}{|l|}{ Cooperative type dummies ${ }^{b}$} \\
\hline $\mathrm{LVCs}^{2}$ & 241.172 & $(307.961)$ & 237.672 & $(345.682)$ & 0.809 & $(0.503)$ \\
\hline $\mathrm{NRCs}^{2}$ & 344.344 & $(292.576)$ & 325.124 & $(331.079)$ & 0.854 & $(0.465)^{*}$ \\
\hline Constant & 325.769 & $(618.477)$ & -988.826 & $(858.134)$ & -3.545 & $(0.938)^{* * *}$ \\
\hline Athrho_constant & & & & & -0.486 & $(0.153)^{* * *}$ \\
\hline Lnsigma_constant & & & & & 6.827 & $(0.051)^{* * *}$ \\
\hline Mill's lambda & & & & & -415.851 & $(124.108)$ \\
\hline \multicolumn{7}{|l|}{ Summary statistics } \\
\hline R-squared & 17.60 & & & & & \\
\hline Number of observations & 276 & & & 431 & & \\
\hline Censored observations & & & & 188 & & \\
\hline Uncensored observations & & & & 243 & & \\
\hline Log likelihood & & & & $-2,164.691$ & & \\
\hline Wald test & & & \multicolumn{4}{|c|}{$\operatorname{chi} 2(22)=57.29$, Prob. $>$ chi $2=0.000$} \\
\hline LR test for indep. eqns. $($ rho $=0)$ & & & \multicolumn{4}{|c|}{$\operatorname{chi} 2(1)=4.28$, Prob. $>\operatorname{chi} 2=0.039$} \\
\hline Mill's lambda & \multicolumn{6}{|c|}{ the $95 \%$ confidence interval $[-659.097,-172.605]$} \\
\hline
\end{tabular}


latter may be related to the possibility that more educated leaders might have a better understanding of member-relations to the cooperative and, therefore, strive for high member benefits through the provision of good services and low-price inputs instead of maintaining cooperative profits for economic stability. Our models are not conclusive on the importance of the number of committees a cooperative holds nor support a cooperative received during setup and membership policy. Profit seems to be higher for cooperatives of which board members receive a cash compensation. This finding corroborates with Chareonwongsak (2017), who reported a positive relationship between board members compensation and the cooperative performance.

Conflict is negatively correlated with sales and profit. Recent studies have shown that conflict is a result of member heterogeneity. The presence of such heterogeneity may weaken the organizational structure by affecting investment behavior, collective decision-making costs, and members commitment, potentially contributing to a cooperative's demise (Chaddad and Cook, 2007; Fulton and Hueth, 2009; Gripsrud et al., 2001; Hoehler and Kuehl, 2018; Iliopoulos and Valentinov, 2017; Kalogeras et al., 2009).

The result on the presence of women directors is puzzling and may be due to the limited number of women directors. The models suggest a negative correlation with sales per member and profit. The negative correlation with sales per member and profit may be due to the fact that regulations encourage women members to be elected to the board of directors through gender quota rather than merit-based selection. Consequently, women will end up with a passive role with men usually dominating the decision-making. Women may also be timeconstrained due to their responsibilities in the households' production and reproduction activities. They may also be more limited in establishing socio-political networks compared to men (Barham and Chitemi, 2009), which hinders their participation in stimulating customer demand, which in turn leads to lower sales and profit. The finding is consistent with Grashuis and Cook (2016), who also report on a negative correlation between women directors and performance. Contrary to our expectations, closed membership policy seemed not to matter for the performance of the cooperative.

\section{- External linkages, support, and location}

Having business links with other cooperatives is negatively correlated with sales per member, yet positively correlated with profit. The latter positive effect may relate to the reduction in transaction costs while dealing with other organizations. This result is consistent with the findings of Ragasa and Golan (2014). Yet, transaction costs may be less important for sales values and explain the negative effects on sales per member. Moreover, competition for potential members may have implications for sales volume.

Union membership is negatively correlated with sales and profit. This finding contradicts with those of Ragasa and Golan (2014), who found that being a member of umbrella organizations had a positive correlation with the performance of rural producer organizations. Actually, unions are established to provide services which the cooperatives are normally not able to access. In the study area, most cooperatives did not seem to benefit from a union membership. This could be due to several reasons including impacts on price (union charges higher price than the market), quality (union supplies unsafe or defective products), quantity and timing of product delivery, and transport cost. This result is consistent with the many complaints we heard during respondents' interview regarding union service delivery system.

Some interesting results on the probability to be audited stand out. Older cooperatives and those with more members have a higher probability to be audited (Table 5). The latter may be due to a pressure of more members on the cooperative to conduct audit and affect timely distribution of dividends. On the contrary, we find that cooperatives with less capital have are more likely to be audited. Audit service providers may prefer cooperatives with smaller amount of capital, with low transaction activities. Not surprisingly, having an office is positively correlated to the probability for audit. This is because having an office with key facilities and located at a known area is a basic requirement to receive an audit service. In the case of governance indicators, the level of education of the board is found to be positively correlated with audit. This may generally point to a higher level of education creating a higher sense of awareness about the benefit of audit 
and more likely to take part in maintaining records and periodic reports. The presence of an audit committee is positively associated with the likelihood of receiving an audit. Hence, cooperatives whose audit committee invests time in preparing accounting entries, are likely to take part in an audit. Moreover, cooperatives that prepared financial statements have a higher probability for receiving an audit.

In order to check the robustness of our results, we run a separate OLS model for each cooperative type (Table 6). The results are in line with those presented above. Additionally, the variable indicating that board members would receive a compensation, was positive in the sales model for MPCs. The variable signaling a presence of conflict in a cooperative has a negative coefficient in the sales model for NRCs which contradicts Tadesse and Kassie (2017). Union membership had a negative coefficient in the sales model for MPCs. Business links with other cooperatives is negatively correlated to sales for LVCs. In addition to the regression models by each type of cooperative, we also present alternative models with selected variables in Supplementary Table S2, which serve as robustness checks. The results are similar to those shown in the full model of Table 4.

Table 6. Effects of log transformed sales by cooperative type. ${ }^{1}$

\begin{tabular}{|c|c|c|c|}
\hline \multirow[b]{2}{*}{ Independent variables } & \multicolumn{3}{|l|}{$\operatorname{Ln}^{2}$ (total sales) } \\
\hline & $\mathrm{MPCs}^{2}$ & $\mathrm{LVCs}^{2}$ & $\mathrm{NRCs}^{2}$ \\
\hline \multicolumn{4}{|l|}{ Chairperson characteristics } \\
\hline Chairperson education & $-0.030(0.152)$ & $-0.114(0.213)$ & $-0.369(0.489)$ \\
\hline Chairperson education squared & $-0.004(0.013)$ & $0.002(0.014)$ & $0.015(0.041)$ \\
\hline Chairperson working experience & $-0.007(0.032)$ & $-0.202(0.132)$ & $0.218(0.154)$ \\
\hline \multicolumn{4}{|l|}{ Institutional characteristics } \\
\hline Age of cooperative & $0.002(0.016)$ & $0.156(0.105)$ & $-0.192(0.130)$ \\
\hline $\mathrm{Ln}^{2}$ (membership size) & $0.370 * *(0.182)$ & $1.134 * * *(0.362)$ & $0.421 * *(0.377)$ \\
\hline $\mathrm{Ln}^{2}$ (cooperative size in assets) & $-0.016(0.034)$ & $0.178 * * *(0.065)$ & $0.258 * * *(0.081)$ \\
\hline Employees & $-0.050(0.775)$ & $0.253(0.465)$ & $-0.001(0.757)$ \\
\hline Office & $0.525(0.548)$ & $0.528(0.481)$ & $1.077(0.969)$ \\
\hline \multicolumn{4}{|l|}{ Governance characteristics } \\
\hline Number of committees & $-0.142(0.106)$ & $-0.032(0.158)$ & $0.080(0.280)$ \\
\hline Women directors & $-0.112(0.135)$ & $-0.072(0.183)$ & $-0.144(0.357)$ \\
\hline Board education & $-0.039(0.063)$ & $0.223 *(0.123)$ & $0.086(0.224)$ \\
\hline Board compensation & $0.379(0.302)$ & $6.038 * * *(1.760)$ & $0.381(1.928)$ \\
\hline Conflict experience & $-0.161(0.249)$ & $-0.173(0.472)$ & $-2.171 * * *(0.810)$ \\
\hline Membership policy & $0.203(1.076)$ & $0.618(0.468)$ & $-0.099(0.834)$ \\
\hline \multicolumn{4}{|l|}{ External linkages and support } \\
\hline Received help during setup & $0.383(0.281)$ & $-0.065(0.558)$ & $0.504(0.827)$ \\
\hline Business links with others coop & $0.213(0.262)$ & $-0.777 *(0.471)$ & $0.222(0.808)$ \\
\hline Union membership & $-2.037 * * *(0.517)$ & $0.714(0.555)$ & $1.166(0.935)$ \\
\hline \multicolumn{4}{|l|}{ Location-zone dummies $^{\mathrm{a}}$} \\
\hline Central & $-0.175(0.352)$ & $1.442 * *(0.599)$ & $-0.391(1.103)$ \\
\hline South and southeastern & $-1.081 * * *(0.337)$ & $1.058(0.653)$ & $0.279(1.074)$ \\
\hline West and northwestern & $0.232(0.338)$ & $0.053(0.606)$ & $1.127(1.235)$ \\
\hline Constant & $10.110 * * *(1.448)$ & $2.993 *(1.642)$ & $5.794 * *(2.811)$ \\
\hline Number of cooperatives & 177. & 192 & 126 \\
\hline R-squared & 30.56 & 31.27 & 26.17 \\
\hline
\end{tabular}




\section{Conclusions}

In Africa, much research was done on the impact of cooperatives at member-level, but much less is known on the drivers of the economic and financial performance at cooperative level. This paper aims to fill this knowledge gap by studying agricultural cooperatives in north Ethiopia. Agricultural cooperatives in the rural areas of Ethiopia have been attributed important roles in poverty reduction, ensuring food security and development by providing agricultural services to their members.

Some results stand out: (1) we find large variability for the sales and profit indicators we have used for performance and for the cooperative institutional and governance characteristics. (2) Many indicators related to the chairperson characteristics seem not to be clearly associated with performance. (3) Membership size has a positive correlation with cooperatives' performance. (4) In terms of organizational structure, we find little evidence on the effect of board members' cash compensation on economic and financial results. We also did not find differences in the performance between closed and open membership cooperatives, most probably because this is linked to the type of cooperative for which we control in the analysis. (5) Cooperatives with low level of conflict seem to perform better in terms of sales. This effect is mainly found for NRCs, where access to resources may lead to disagreements. (6) The horizontal linkage among cooperatives is very weak as perhaps the link is at its infant stage and little recognition is given to the benefits of networking. The vertical integration of cooperatives with unions seems to influence performance negatively. (7) Cooperative performance is also determined by the geographical location. The coefficients for the West and northwestern zone turn out to be positive and significant for-profit, relative to cooperatives in other zones. This analysis of unique cooperative-level data shows the large variability in performance across the studied agricultural cooperatives. This variability is partly explained by the characteristics of the cooperative chairperson, but even more by institutional and governance characteristics including the membership size, total assets, presence of conflict among members and union membership.

\section{Acknowledgements}

The authors are grateful for the help they received from the Cooperative Promotion Agency, the district officers, the facilitators, the chairpersons, the vice-chairpersons and the members of the cooperatives that participated in this research. We thank the Flemish University Council for financing this research (VLIR UOS TEAM project ZEIN2015PR406).

\section{Supplementary material}

Supplementary material can be found online at https://doi.org/10.22434/IFAMR2019.0215

Table S1. Variables and descriptions.

Table S2. Determinants of log transformed sales (OLS model).

\section{Declaration of conflicting interests}

The author(s) declare no potential conflicts of interest with respect to the research, authorship, and /or publication of this article.

\section{References}

Abate, G.T., G.N. Francesconi and K. Getnet. 2014. Impact of agricultural cooperatives on smallholders technical efficiency: empirical evidence from Ethiopia. Annals of Public and Cooperative Economics 85(2): 257-286.

Abebaw, D. and M.G. Haile. 2013. The impact of cooperatives on agricultural technology adoption: empirical evidence from Ethiopia. Food Policy 38(1): 82-91. 
Adams, R.B. and D. Ferreira. 2009. Women in the boardroom and their impact on governance and performance. Journal of Financial Economics 94(2): 291-309.

Adrian Jr, J.L. and T.W. Green. 2001. Agricultural cooperative managers and the business environment. Journal of Agribusiness 19: 17-33.

Ahmed, M.H. and H.M. Mesfin. 2017. The impact of agricultural cooperatives membership on the wellbeing of smallholder farmers: empirical evidence from eastern Ethiopia. Agricultural and Food Economics 5: 6.

Ahn, S.C., J.C. Brada and J.A. Méndez. 2012. Effort, technology and the efficiency of agricultural cooperatives. Journal of Development Studies 48(11): 1601-1616.

Alho, E. 2015. Farmers' self-reported value of cooperative membership: evidence from heterogeneous business and organization structures. Agricultural and Food Economics 3(1): 23.

Arcas-Lario, N., J.F. Martín-Ugedo and A. Mínguez-Vera. 2014. Farmers' satisfaction with fresh fruit and vegetable marketing Spanish cooperatives: an explanation from agency theory. International Food and Agribusiness Management Review 17(1): 127-146.

Ariyaratne, C.B., A.M. Featherstone and M.R. Langemeier. 2006. What determines productivity growth of agricultural cooperatives? Journal of Agricultural and Applied Economics 38(1): 47-59.

Ariyaratne, C.B., A.M. Featherstone, M.R. Langemeier and D.G. Barton. 2000. Measuring X-efficiency and scale efficiency for a sample of agricultural cooperatives. Agricultural and Resource Economics Review 29(2): 198-207.

Barham, J. and C. Chitemi. 2009. Collective action initiatives to improve marketing performance: lessons from farmer groups in Tanzania. Food Policy 34(1): 53-59.

Bengtsson, M. and S. Kock. 1999. Cooperation and competition in relationships between competitors in business networks. Journal of Business and Industrial Marketing 14(3): 178-194.

Benos, T., N. Kalogeras, F.J. Verhees, P. Sergaki and J.M. Pennings. 2016. Cooperatives' organizational restructuring, strategic attributes, and performance: the case of agribusiness cooperatives in Greece. Agribusiness 32(1): 127-150.

Benos, T., N. Kalogeras, M. Wetzels, K. De Ruyter and J.M. Pennings. 2018. Harnessing a 'currency matrix' for performance measurement in cooperatives: a multi-phased study. Sustainability 10(12): 4536.

Benson, T. 2014. Building good management practices in Ethiopian agricultural cooperatives through regular financial audits. Journal of Co-operative Organization and Management 2(2): 72-82.

Bernard, T., G.T. Abate and S. Lemma. 2013. Agricultural cooperatives in Ethiopia: results of the 2012 ATA baseline survey. International Food Policy Research Institute, Washington, DC, USA, pp. 1-23.

Bernard, T., M.H. Collion, A. De Janvry, P. Rondot and E. Sadoulet. 2008a. Do village organizations make a difference in African rural development? A study for Senegal and Burkina Faso. World Development 36(11): 2188-2204.

Bernard, T. and D.J. Spielman. 2009. Reaching the rural poor through rural producer organizations? A study of agricultural marketing cooperatives in Ethiopia. Food Policy 34(1): 60-69.

Bernard, T., D.J. Spielman, A.S Taffesse and E.Z. Gabre-Madhin. 2010. Cooperatives for staple crop marketing: evidence from Ethiopia. Research monography 164. International Food Policy Research Institute, Washington, DC, USA.

Bernard, T., A.S. Taffesse and E. Gabre-Madhin. 2008b. Impact of cooperatives on smallholders' commercialization behavior: evidence from Ethiopia. Agricultural Economics 39(2): 147-161.

Bhuyan, S. 2007. The 'people' factor in cooperatives: an analysis of members' attitudes and behavior. Canadian Journal of Agricultural Economics 55(3): 275-298.

Bond, J.K. 2009. Cooperative financial performance and board of director characteristics: a quantitative investigation. Journal of Cooperatives 22: 22-44.

Bourne, M., A. Neely, J. Mills and K. Platts. 2003. Implementing performance measurement systems: a literature review. International Journal of Business Performance Management 5(1): 1-24.

Boyd, S., M. Boland, K. Dhuyvetter and D. Barton. 2007. Determinants of return on equity in US local farm supply and grain marketing cooperatives. Journal of Agricultural and Applied Economics 39(1): 201-210. 
Burress, M.J. and M.L. Cook. 2010. Director development and board-CEO relations: do recommendations from corporate governance apply to the agribusiness cooperative. Working paper, University of Missouri, Columbia, MO, USA.

Cai, R., W. Ma and Y. Su. 2016. Effects of member size and selective incentives of agricultural cooperatives on product quality. British Food Journal 118(4): 858-870.

Carpenter, M.A. and J.D. Westphal. 2001. The strategic context of external network ties: examining the impact of director appointments on board involvement in strategic decision making. Academy of Management Journal 44(4): 639-660.

Carter, D.A., B.J. Simkins and W.G. Simpson. 2003. Corporate governance, board diversity, and firm value. Financial Review 38(1): 33-53.

Cechin, A., J. Bijman, S. Pascucci, D. Zylbersztajn and O. Omta. 2013. Quality in cooperatives versus investor-owned firms: evidence from broiler production in Paraná, Brazil. Managerial and Decision Economics 34(3-5): 230-243.

Chaddad, F.R. and M.L. Cook. 2007. Conversions and other forms of exit in US agricultural cooperatives. In: K. Karantininis and J. Nilsson (eds.) Vertical markets and cooperative hierarchies. Springer, Berlin, Germany, pp. 61-72.

Chagwiza, C., R. Muradian and R. Ruben. 2016. Cooperative membership and dairy performance among smallholders in Ethiopia. Food Policy 59: 165-173.

Chareonwongsak, K. 2017. Enhancing board motivation for competitive performance of Thailand's cooperatives. Journal of Co-operative Organization and Management 5(1): 1-13.

Cook, M.L. 1994. The role of management behavior in agricultural cooperatives. Journal of Agricultural Cooperation: $42-58$.

Cook, M.L. 1995. The future of US agricultural cooperatives: a neo-institutional approach. American Journal of Agricultural Economics 77(5): 1153-1159.

Cook, M.L. and M.J. Burress. 2013. The impact of CEO tenure on cooperative governance. Managerial and Decision Economics 34(3-5): 218-229.

Dess, G.G. and R.B. Robinson Jr. 1984. Measuring organizational performance in the absence of objective measures: the case of the privately-held firm and conglomerate business unit. Strategic Management Journal 5(3): 265-273.

Emana, B. 2009. Cooperatives: a path to economic and social empowerment in Ethiopia. Working Paper 995017193202676, International Labour Organization, Geneva, Switzerland.

Ethiopian Agricultural Transformation Agency (ATA). 2012. Agricultural cooperatives sector development strategy 2012-2106. Ethiopian Agricultural Transformation Agency, Addis Ababa, Ethiopia.

Ethiopian Federal Cooperative Agency (FCA). 2015. Cooperative movement in Ethiopia: performances, challenges and intervention options. Ethiopian Federal Cooperative Agency, Addis Ababa, Ethiopia.

Ethiopian Ministry of Finance and Economic Development (MoFED). 2010. Growth and transformation plan. Vol. I. Ministry of Finance and Economic Development, Addis Ababa, Ethiopia.

Feng, L., A. Friis and J. Nilsson. 2016. Social capital among members in grain marketing cooperatives of different sizes. Agribusiness 32(1): 113-126.

Feng, L. and G.W. Hendrikse. 2012. Chain interdependencies, measurement problems and efficient governance structure: cooperatives versus publicly listed firms. European Review of Agricultural Economics 39(2): 241-255.

Figueiredo, V. and M. Franco. 2018. Factors influencing cooperator satisfaction: a study applied to wine cooperatives in Portugal. Journal of Cleaner Production 191: 15-25.

Fischer, E. and M. Qaim. 2012. Linking smallholders to markets: determinants and impacts of farmer collective action in Kenya. World Development 40(6): 1255-1268.

Francesconi, G.N. and R. Ruben. 2008. The life cycle of agricultural cooperatives: implications for management and governance in Ethiopia. Journal of Rural Cooperation 36: 115-130.

Franken, J.R. and M.L. Cook. 2015. Informing measurement of cooperative performance. In Interfirm networks: franchising, cooperatives and strategic alliances. Springer, Berlin, Germany, pp. 209-226.

Fulton, M.E. and B. Hueth. 2009. Cooperative conversions, failures and restructurings: an overview. Journal of Cooperatives 23: 1-11. 
Galdeano-Gómez, E., J. Céspedes-Lorente and M. Rodríguez-Rodríguez. 2006. Productivity and environmental performance in marketing cooperatives: an analysis of the Spanish horticultural sector. Journal of Agricultural Economics 57(3): 479-500.

Gentzoglanis, A. 1997. Economic and financial performance of cooperatives and investor-owned firms: an empirical study. In: J. Nilsson and G. Van Dijk (eds.) Strategies and structures in the agro-food industries. Van Gorcum, Assen. the Netherlands, pp. 171-183.

Getnet, K. and T. Anullo. 2012. Agricultural cooperatives and rural livelihoods: evidence from Ethiopia. Annals of Public and Cooperative Economics 83(2): 181-198.

Grashuis, J. 2018. A quantile regression analysis of farmer cooperative performance. Agricultural Finance Review 78(1): 65-82.

Grashuis, J. and M. Cook. 2016. Governance and performance in the US agri-food industry: a comparative study of firms and cooperatives. Annual Meeting, Agricultural and Applied Economics Association. July 31-August 2, 2016. Boston, MA, USA.

Grashuis, J. and Y. Su. 2019. A review of the empirical literature on farmer cooperatives: performance, ownership and governance, finance, and member attitude. Annals of Public and Cooperative Economics 90(1): 77-102.

Gripsrud, G., G.H. Lenvik and N.V. Olsen. 2001. Influence activities in agricultural cooperatives: the impact of heterogeneity. In: Proceedings of NJF-seminar - The food sector in transition-Nordic research. Norwegian Agricultural Economics Research Institute, Oslo, Norway, pp. 13-24.

Guzmán, I. and N. Arcas. 2008. The usefulness of accounting information in the measurement of technical efficiency in agricultural cooperatives. Annals of Public and Cooperative Economics 79(1): 107-131.

Guzmán, I., N. Arcas, R. Ghelfi and S. Rivaroli. 2009. Technical efficiency in the fresh fruit and vegetable sector: a comparison study of Italian and Spanish firms. Fruits 64(4): 243-252.

Hailu, G., E.W. Goddard and S.R. Jeffrey. 2005. Measuring efficiency in fruit and vegetable marketing co-operatives with heterogeneous technologies in Canada. Annual meeting, American Agricultural Economics Association. July 24-27, 2005. Providence, RI, USA.

Hansen, M.H., J.L. Morrow Jr and J.C. Batista. 2002. The impact of trust on cooperative membership retention, performance, and satisfaction: an exploratory study. International Food and Agribusiness Management Review 5(1): 41-59.

Hardin, R. 1982. Collective action. Johns Hopkins University Press, Baltimore, MA, USA.

Harrington, D.R. 1993. Corporate financial analysis: decisions in a global environment. Richard d Irwin, Homewood, IL, USA.

Heckman, J. 1979. Sample selection as a specification error. Econometrica 47: 153-161.

Hoehler, J. and R. Kuehl. 2018. Dimensions of member heterogeneity in cooperatives and their impact on organization - a literature review. Annals of Public and Cooperative Economics 89(4): 697-712.

Hovelaque, V., S. Duvaleix-Tréguer and J. Cordier. 2009. Effects of constrained supply and price contracts on agricultural cooperatives. European Journal of Operational Research 199(3): 769-780.

Huang, Z., Y. Fu, Q. Liang, Y. Song and X. Xu. 2013. The efficiency of agricultural marketing cooperatives in China's Zhejiang province. Managerial and Decision Economics 34(3-5): 272-282.

Hueth, B. and P. Marcoul. 2009. Incentive pay for CEOs in cooperative firms. American Journal of Agricultural Economics 91(5): 1218-1223.

Iliopoulos, C. and V. Valentinov. 2017. Member preference heterogeneity and system-lifeworld dichotomy in cooperatives: an exploratory case study. Journal of Organizational Change Management 30(7): 1063-1080.

Jensen, M.C. 1993. The modern industrial revolution, exit, and the failure of internal control systems. The Journal of Finance 48(3): 831-880.

Kalogeras, N., J.M. Pennings, I.A. Van der Lans, P. Garcia and G. Van Dijk. 2009. Understanding heterogeneous preferences of cooperative members. Agribusiness: an International Journal 25(1): 90-111.

Karami, E. and K. Rezaei-Moghaddam. 2005. Modeling determinants of agricultural production cooperatives' performance in Iran. Agricultural Economics 33(3): 305-314.

Karantininis, K. and A. Zago. 2001. Endogenous membership in mixed duopsonies. American Journal of Agricultural Economics 83(5): 1266-1272. 
Kellogg, I. and L.B. Kellogg. 1991. Fraud, window dressing, and negligence in financial statements. Vol. 1. Shepards/McGraw-Hill, Boston, MA, USA.

Klimek, P., R. Hanel, and S. Thurner. 2009. Parkinson's law quantified: three investigations on bureaucratic inefficiency. Journal of Statistical Mechanics: Theory and Experiment 2009: P03008.

Krahnen, J.P. and R.H. Schmidt. 1995. On the theory of credit cooperatives: equity and onlending in a multitier system: a concept paper: Enterprise and Cooperative Development Department, International Labour Office, Geneva, Switzerland.

Liang, Q., Z. Huang, H. Lu and X. Wang. 2015. Social capital, member participation, and cooperative performance: evidence from China's Zhejiang. International Food and Agribusiness Management Review 18: 49.

Liebrand, C.B. and K.C. Ling. 2014. Member satisfaction with their cooperatives: insights from dairy farmers. Research Report 229, USDA Rural Development, Washington, DC, USA.

Lin, C., F.M. Song and Z. Sun. 2012. The financial implications of corporate fraud. AFA 2013 Meetings Paper, San Diego, CA, USA.

Ling, K.C. 2005. Dairy cooperative growth challenges: technology, ingredients (proteins) and equity financing. Research Report 280094, USDA Rural Development, Washington, DC, USA.

Mathuva, D. 2016. Revenue diversification and financial performance of savings and credit co-operatives in Kenya. Journal of Co-operative Organization and Management 4(1): 1-12.

Mathuva, D.M., E.W. Muthuma and J.M. Kiweu. 2016. The impact of name change on the financial performance of savings and credit co-operatives in Kenya. Management Research Review 39(10): 1265-1292.

McMullen, D.A. and K. Raghunandan. 1996. Enhancing audit committee effectiveness. Journal of Accountancy 182(2): 79 .

Melia-Marti, E. and A.M. Martinez-Garcia. 2015. Characterization and analysis of cooperative mergers and their results. Annals of Public and Cooperative Economics 86(3): 479-504.

Ménard, C. 2004. The economics of hybrid organizations. Journal of Institutional and Theoretical Economics 160(3): 345-376.

Mérel, P.R., T.L. Saitone and R.J. Sexton. 2009. Cooperatives and quality-differentiated markets: strengths, weaknesses, and modeling approaches. Journal of Rural Cooperation 37: 201.

Mojo, D., C. Fischer and T. Degefa. 2017. The determinants and economic impacts of membership in coffee farmer cooperatives: recent evidence from rural Ethiopia. Journal of Rural Studies 50: 84-94.

Nilsson, J. 2001. Organisational principles for co-operative firms. Scandinavian Journal of Management 17(3): 329-356.

Olson, M. 1965. The logic of collective action. Harvard University Press, Cambridge, MA, USA.

Pennerstorfer, D. and C.R. Weiss. 2012. Product quality in the agri-food chain: do cooperatives offer highquality wine? European Review of Agricultural Economics 40(1): 143-162.

Pindyck, R.S. and D.L. Rubinfeld. 1998. Econometric models and economic forecasts. Vol. 4. Irwin/McGrawHill, Boston, MA, USA.

Pozzabon, D.M., D. Zylbersztajn and J. Bijman. 2012. How can cooperatives reduce democratic costs without incurring excessive agency costs? Journal of Rural Cooperation 40: 119-144.

Ragasa, C. and J. Golan. 2014. The role of rural producer organizations for agricultural service provision in fragile states. Agricultural Economics 45(5): 537-553.

Rankin, M., A. Dunne and I. Russell. 2007. The development of market-oriented cooperatives within the fruit industry in the Mekong Delta, Vietnam: a theory building approach to understanding rural development outcomes. International Symposium on Improving the Performance of Supply Chains in the Transitional Economies. September 23, 2007. Hanoi, Vietnam, 794 pp.

Rose, C. 2007. Does female board representation influence firm performance? The Danish evidence. Corporate Governance: an International Review 15(2): 404-413.

Royer, J.S. 2014. The theory of agricultural cooperatives: a neoclassical primer. University of NebraskaLincoln, Lincoln, NE, USA.

Salmi, T. and T. Martikainen. 1994. A review of the theoretical and empirical basis of financial ratio analysis. The Finnish Journal of Business Economics 4: 426-448. 
Sexton, R.J., B.M. Wilson and J.J. Wann. 1989. Some tests of the economic theory of cooperatives: methodology and application to cotton ginning. Western Journal of Agricultural Economics 14: 56-66.

Shumeta, Z. and M. D'Haese. 2016. Do coffee cooperatives benefit farmers? An exploration of heterogeneous impact of coffee cooperative membership in Southwest Ethiopia. International Food and Agribusiness Management Review 19(4): 37-52.

Sisay, D.T., J. Frans and C. Hans. 2017. Marketing activities as critical success factors: the case of seed producer cooperatives in Ethiopia. African Journal of Business Management 11(19): 548-563.

Soboh, R.A., A.O. Lansink, G. Giesen and G. Van Dijk. 2009. Performance measurement of the agricultural marketing cooperatives: the gap between theory and practice. Review of Agricultural Economics 31(3): 446-469.

Spear, R. 2004. Governance in democratic member-based organisations. Annals of Public and Cooperative Economics 75(1): 33-60.

Spielman, D. and T. Bernard. 2008. Mobilizing rural institutions for sustainable livelihoods and equitable development: a case study of farmer cooperatives in Ethiopia: an overview. Final Report, International Food Policy Research Institute, Washington, DC, USA.

Staatz, J.M. 1983. The cooperative as a coalition: a game-theoretic approach. American Journal of Agricultural Economics 65(5): 1084-1089.

Sueyoshi, T., T. Hasebe, F. Ito, J. Sakai and W. Ozawa. 1998. DEA-bilateral performance comparison: an application to Japan agricultural co-operatives (Nokyo). Omega 26(2): 233-248.

Susanty, A., A. Bakhtiar, F. Jie and M. Muthi. 2017. The empirical model of trust, loyalty, and business performance of the dairy milk supply chain: a comparative study. British Food Journal 119(12): 2765-2787.

Tadesse, G. and G.T. Kassie. 2017. Measuring trust and commitment in collective actions: evidence from farmers' marketing organizations in rural Ethiopia. International Journal of Social Economics 44(7): 980-996.

Tana, W., J.M.C. de Mesquita, C.A. Gonçalves and H.C. Martins. 2017. Social networks, social capital and performance: a study with Brazilian dairy cooperatives. Revista de Ciências da Administração 19(48): 38-53.

Tigray Cooperative Promotion Agency (TCPA). 2017. Performance of agricultural cooperatives in Tigray region. Annual bulletin report. Tigray Cooperative Promotion Agency, Mekelle, Tigray, Ethiopia.

Tefera, D.A., J. Bijman and M.A. Slingerland. 2017. Agricultural co-operatives in Ethiopia: evolution, functions and impact. Journal of International Development 29(4): 431-453.

Verbeek, M. 2008. A guide to modern econometrics. John Wiley \& Sons, Hoboken, NJ, USA.

Verhofstadt, E. and M. Maertens. 2014. Smallholder cooperatives and agricultural performance in Rwanda: do organizational differences matter? Agricultural Economics 45(1): 39-52.

Verhofstadt, E. and M. Maertens. 2015. Can agricultural cooperatives reduce poverty? Heterogeneous impact of cooperative membership on farmers' welfare in Rwanda. Applied Economic Perspectives and Policy 37: 86-106.

Wanyama, F.O., P. Develtere and I. Pollet. 2009. Reinventing the wheel? African cooperatives in a liberalized economic environment. Annals of Public and Cooperative Economics 80(3): 361-392.

Wollni, M. and E. Fischer. 2015. Member deliveries in collective marketing relationships: evidence from coffee cooperatives in Costa Rica. European Review of Agricultural Economics 42(2): 287-314.

Wossen, T., T. Abdoulaye, A. Alene, M.G. Haile, S. Feleke, A. Olanrewaju and V. Manyong. 2017. Impacts of extension access and cooperative membership on technology adoption and household welfare. Journal of Rural Studies 54: 223-233.

Wouterse, F. and G.N. Francesconi. 2016. Organisational health and performance: an empirical assessment of smallholder producer organisations in Africa. Journal on Chain and Network Science 16(1): 29-40.

Yang, S. and F.R. Chaddad. 2014. The relationship between performance and governance in agricultural co-operatives. A structural equation modeling approach. MSc-thesis, University of Missouri, Columbia, MO, USA.

Yermack, D. 1996. Higher market valuation of companies with a small board of directors. Journal of Financial Economics 40(2): 185-211. 
